\title{
Further Evidence Of The Creation Of Value Through The Management Of Net Working Capital: An Analysis Of S\&P 500 Firms
}

Rakesh Duggal, Southeastern Louisiana University, USA

Michael Craig Budden, Southeastern Louisiana University, USA

\begin{abstract}
Net working capital is defined as the difference between current assets and current liabilities. A firm's net working capital policy is important because it affects the firm's cost of capital and market value. When net working capital is positive, it indicates that the firm is using long-term funds from lenders and/or shareholders to finance its current assets. Since long-term funds, in general, are more expensive than short-term funds, theoretically, the greater use of net working capital will increase the firm's cost of capital and lower its market value, ceteris paribus. Consistent with the theory's prediction, this study finds a negative relationship between the amount of net working capital used by $S \& P 500$ firms and risk-adjusted shareholder returns in the 2009-2012 period.
\end{abstract}

Keywords: Value Creation; Net Working Capital; S\&P 500; Profitability; Risk

\section{INTRODUCTION}

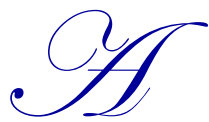

firm needs working capital or current assets for running its operating cycle. Although it is conceivable for a firm to finance its current assets completely with either short-term (zero net working capital) or long-term financing (net working capital equals the firm's current assets), firms generally select a mix of short-term and long-term financing and this mix is affected by many variables, including the firm's industry conventions, market share, and management's risk preferences. Industry conventions pertaining to terms of sale develop over a long period of time and change little. These conventions are affected by the industry's business risk reflected in numerous factors such as the durable nature of the goods, cost of capital, margin of profit, and regulations. For example, firms operating in a perishable goods industry that buy/sell on very short credit terms manage their working capital with a minimal use of long-term financing.

On the other hand, in a capital intensive durable goods industry firms have to use more long-term funds to finance their inventories and receivables. However, larger firms with a significant share of the market are able to extract better terms from both their vendors and buyers so these firms will tend to use less net working capital than the industry average. For example, Dell was a pioneer in extracting longer terms from its vendors and the firm had a negative net working capital, meaning that Dell was using vendor financing to finance its fixed assets (BusinessWeek, 2002). Anecdotal evidence suggests that Walmart and Apple are using the same strategy to lower their net working capital needs to create value (Wall Street Journal, 2012). Finally, the greater risk tolerance of some firms' managers might cause some firms to use more short-term financing, contrary to the industry's norms. However, it is important to note that, unlike Dell and other companies that try to create value at their vendors' expense, the managers' use of a lower amount of net working capital might not succeed in lowering the firm's cost of capital. This is because any sub-optimal mix of short-term and long-term financing might adversely affect the cost of capital, especially if the mix affects the volatility of cash flows to the providers of capital. 


\section{PRIOR RESEARCH}

Earlier research on working capital management focused on the impact of net working capital on the firm's profitability or return on equity. For example, Shin and Soenen (1998) researched the relationship between working capital management and value creation for shareholders. They used the cash conversion cycle (CCC), as a proxy for working capital management. The cash conversion cycle reflects the time span between disbursement and collection of cash. They argue that firms create profits for their companies by handling correctly the cash conversion cycle and by keeping accounts receivables at an optimal level. They found a strong negative relationship between the length of the firm's net-trade cycle and its profitability. Gill, Biger, and Mathur (2010), also found a statistically significant relationship between the cash conversion cycle and profitability, measured through gross operating profit. Similarly, Garcia-Teuruel and Martinez-Solano (2007) report a positive relationship between firm profitability and improvement in working capital management.

More recently, Kieschnick, LaPlante, and Moussawi (2013) have found that an incremental dollar invested in net operating capital is worth less than an incremental dollar held in cash for the average firm. This research differs from prior research in three ways. First, the study shows that there are industry differences in working capital management practices and adjusts for these differences. Second, the study uses risk-adjusted shareholder returns as opposed to the book value-based profitability measures. Finally, the study uses the most comprehensive value for net working capital (current asset less current liabilities) that takes into account overall working capital management efficiency.

\section{SAMPLE AND RESEARCH DESIGN}

All S\&P 500 firms, except the financial firms, comprise this study's sample. However, due to missing data, the sample size was reduced to 363 firms. Using the 2009-2012 average values for the variables, this study tested the hypothesis of a negative relationship between a firm's net working capital and returns to its shareholders. The Treynor index was used to estimate risk-adjusted shareholder returns, as follows:

$\left(\right.$ Return $\left._{\mathrm{i}}-\mathrm{R}_{\mathrm{f}}\right) /$ Beta $_{\mathrm{i}}$,

Where,

Return $_{\mathrm{i}}$ is the annualized total stock return to $i$ th shareholders,

$\mathrm{R}_{\mathrm{f}}$ is the risk free rate,

Beta $_{\mathrm{i}}$ is the $i$ th firm's Beta.

Net working capital, the main independent variable, was estimated as the difference between current assets and current liabilities. In addition, four components of net working capital, namely, cash, accounts receivable, inventory, and notes payable were also used in regressions to see how these balances affect shareholder wealth. Each dependent variable was divided by the firm's sales to address the size effect. Further, as explained in the next section, each dependent variable was adjusted for the industry effect by subtracting the industry median from the variable value.

\section{FINDINGS}

Table 1 displays mean values for the variables of interest. As might be expected, there are differences in the use of net working capital across the nine industries. The telecommunications industry, which is very capital intensive, uses $\$ 2.59$ billion from vendors and other short-term financing sources to finance its investments in fixed assets, while the information technology industry, which is characterized by greater uncertainty, uses $\$ 2.286$ billion of long-term financing. In light of greater business uncertainty facing them, information technology and industrial firms hold the most cash. On the other hand, utilities, known to experience more predictable cash flows maintain 
the smallest cash balances. The consumer staples industry provided the highest annualized return (unadjusted for risk) to shareholders, and the energy sector produced the lowest return in 2009-2012.

Table 1

The mean values of the variables in the 2009-2012 period for the S\&P 500 firms used in this study are indicated. Net working capital is defined as the difference between current assets and current liabilities. All dollar amounts are in millions.

\begin{tabular}{lcccccc}
\hline \multicolumn{1}{c}{ Industry } & $\begin{array}{c}\text { Net Working } \\
\text { Capital }\end{array}$ & Cash & $\begin{array}{c}\text { Accounts } \\
\text { Receivable }\end{array}$ & Inventory & $\begin{array}{c}\text { Accounts } \\
\text { Payable }\end{array}$ & $\begin{array}{c}\text { Annual } \\
\text { Return } \%\end{array}$ \\
\hline Energy & $\$ 854.58$ & $\$ 782.69$ & $\$ 320.25$ & $\$ 328.37$ & $\$ 642.34$ & $7.43 \%$ \\
\hline Materials & $1,126.98$ & 671.88 & 224.16 & 377.65 & 285.06 & 9.98 \\
\hline Industrials & 726.25 & $1,420.00$ & 491.67 & 438.71 & 365.24 & 13.67 \\
\hline $\begin{array}{l}\text { Consumer } \\
\text { Discretionary }\end{array}$ & 515.30 & 725.88 & 295.08 & 411.97 & 425.79 & 20.19 \\
\hline Consumer Staples & 486.10 & 693.80 & 346.37 & 786.71 & 657.03 & 16.27 \\
\hline Health care & $1,588.50$ & $1,114.33$ & 515.63 & 428.69 & 518.56 & 13.99 \\
\hline $\begin{array}{l}\text { Information } \\
\text { Technology }\end{array}$ & $2,285.94$ & $1,280.74$ & 390.96 & 158.68 & 282.43 & 7.70 \\
\hline Telecomm. & $-2,588.19$ & 961.31 & $1,770.42$ & 107.21 & $1,463.51$ & 10.21 \\
\hline Utilities & 107.73 & 304.25 & 248.96 & 188.29 & 235.96 & 9.64 \\
\hline Sample Mean & 567.02 & 930.62 & 382.49 & 381.80 & 438.95 & 12.94 \\
\hline
\end{tabular}

Table 2 displays the results from an analysis of variance test to determine if there are significant industry differences in the use of net working capital. As Panel B indicates, the mean sum of squares for "between groups" is 3.66 times the mean sum of squares for the "within groups," which is significant at greater than the .05 threshold used. So, the null hypothesis that all industries behave similarly with respect to the use of net working capital, can be rejected. Given this information, all independent variables were adjusted for the industry effect by subtracting the industry median value from each independent variable before conducting the regression analyses.

Table 2

\begin{tabular}{|c|c|c|c|}
\hline \multicolumn{4}{|c|}{$\begin{array}{l}\text { Panel A: Net working capital needed per dollar of sales ((current assets-current liabilities)/sales) by industry during } \\
\text { 2009-2012. }\end{array}$} \\
\hline Industry & Number of Firms & Average & Variance \\
\hline Energy & 40 & 0.153946 & 0.039182 \\
\hline Materials & 27 & 0.21706 & 0.016372 \\
\hline Industrials & 52 & 0.154862 & 0.027965 \\
\hline Consumer Discretionary & 69 & 0.169535 & 0.052815 \\
\hline Consumer Staples & 36 & 0.118941 & 0.02382 \\
\hline Health care & 48 & 0.457885 & 0.929627 \\
\hline Information Technology & 57 & 0.443808 & 0.79093 \\
\hline Telecommunications & 4 & -0.03716 & 0.005497 \\
\hline Utilities & 30 & 0.018833 & 0.010757 \\
\hline
\end{tabular}

Panel B: The ANOVA results for the null hypothesis that all industries have identical mean values for net working capital are presented below.

\begin{tabular}{lcccc}
\hline Source of Variation & Sum of Squares & Degrees of Freedom & Mean Squares & $\begin{array}{c}\text { F Statistic } \\
\text { (Probability) }\end{array}$ \\
\hline Between Groups & 7.947248 & 8 & 0.993406 & $3.66(0.00)$ \\
\hline Within Groups & 96.11811 & 354 & 0.27152 & \\
\hline
\end{tabular}

Table 3 displays the regression results. In model 1, the risk-adjusted stockholder returns (Treynor index values) are regressed on the firms' net working capital needs per dollar of sales. The regression coefficient of the independent variable shows that a one percent increase in net working capital/sales leads to a three percent decrease in risk-adjusted shareholder returns. This relationship is significant at the 10 percent confidence level. In model 2 , the Treynor index values were regressed on the four components of net working capital, namely, cash/sales, accounts receivable/sales, inventory/sales, and accounts payable/sales. The results indicate that, holding the remaining independent variables constant, a one percent increase in cash/sales is associated with a seven percent decrease in risk adjusted returns $(\mathrm{p}=0.07)$. However investments in inventory and vendor financing enhance 
shareholder returns. A one percent increase in inventory/sales and accounts payable/sales is associated with a 9 percent $(\mathrm{p}=0.00)$ and 52 percent increase $(\mathrm{p}=0.02)$, respectively, in shareholder returns. Surprisingly, investments in accounts receivable do not affect shareholder returns $(\mathrm{p}=0.93)$.

Table 3

Results from regressing the risk-adjusted returns, as estimated using the Treynor Index, on net working capital and its components in the 2009-2012 period.

\begin{tabular}{lcc}
\hline \multicolumn{1}{c}{ Variables } & Model 1 & Model 2 \\
\hline Intercept & 0.11 & 0.11 \\
\hline Net Working Capital/Sales & -0.03 & - \\
\hline Cash/Sales & $(0.10)$ & -0.07 \\
\hline \multirow{2}{*}{ Accounts Receivable/Sales } & - & $(0.07)$ \\
\hline \multirow{2}{*}{ Inventory/Sales } & - & 0.02 \\
\hline Accounts Payable/Sales & - & $0.93)$ \\
\hline
\end{tabular}

\section{CONCLUSION}

Net working capital appears to be a costly source of capital due to the fact it is financed by long term suppliers of capital. Therefore, firms that use less net working capital, ceteris paribus, will lower their cost of capital and increase their market values. This study finds a negative relationship between risk-adjusted shareholder returns and net working capital used by a firm. Further, while cash holdings reduce shareholder wealth, investments in inventory and vendor financing create shareholder value.

\section{AUTHOR INFORMATION}

Dr. Rakesh Duggal is Professor of Finance at Southeastern. His research interests include corporate governance, capital structure, institutional investors and cost of capital. E-mail: rduggal@ selu.edu

Dr. Michael Craig Budden is the Benjamin Paul Jones Professor of Retailing at Southeastern. His research interests include intellectual property protection, ethics, business strategy and commercial law. E-mail: mbudden@selu.edu

\section{REFERENCES}

1. BusinessWeek (2002), "How efficient is that company," December 23, 94-96.

2. Garcia-Teruel, P. and Martinez-Solano, P. (2007), "Effects of working capital management on SME profitability," International Journal of Managerial Finance 3, 164-177.

3. Gill, A, N. Biger, and N. Mathur (2010), "The relationship between working capital management and profitability: Evidence from the United States," Business and Economics Journal, 10, http://astonjournals.com/bej.

4. Kieschnick, R., M. LaPlante, and R. Moussawi,(2013), "Working capital Management and shareholder wealth," Review of Finance (17) 5, 1827-1852.

5. Shin H. H. and L. Soenen, (1998), " Efficiency of working capital management and corporate profitability. Financial Practice and Education, 8: 37-45.

6. Wall Street Journal (2012), "Small Firms' big Customers are slow to play," June 6, http://online.wsj.com/news/articles/SB10001424052702303296604577450561434496668 